\title{
Game Theory and the Unrest in Thai Southern Border Provinces
}

\author{
Auschala Chalayonnavin ${ }^{1}$ \\ ${ }^{1}$ Faculty of Social Administration, Thammasat University, Bangkok, Thailand \\ Correspondence: Auschala Chalayonnavin, Faculty of Social Administration, Thammasat University, Bangkok, \\ Thailand. E-mail:auschala2521@gmail.com
}

$\begin{array}{lc}\text { Received: September 1, } 2015 & \text { Accepted: September 25, } 2015 \quad \text { Online Published: October 21, } 2015 \\ \text { doi:10.5539/ass.v11n26p358 } & \text { URL: http://dx.doi.org/10.5539/ass.v11n26p358 }\end{array}$

\begin{abstract}
The unrest in the three southern border provinces of Thailand which occurred in January, 2004 has been reviewed by several different groups of people, especially from the view of the high-level civil servants and politicians. After the problem started, the main inevitable question raised by the society concerned the motives of those individuals or the terrorists who were behind the attack. In this particular case, a generic social theory may not be able to explain the phenomenon of the situation. The members of the public were given various types of information by the state and by other players in the game and were in a "not knowing the enemy and not knowing themselves" interaction with other players. Therefore, through applying the game theory to the unrest in the south of Thailand, people would be able to apply a different aspect of information to make sense of the situation and create a new strategic relationship in the economic interaction with the state and other game players. The interaction, in this case, is the "game" itself.
\end{abstract}

Keywords: terrorists, game theory, Thai's southern border unrest

\section{Backgrounds}

Since January 2004, many violent incidents were committed in the three southern border provinces of Thailand including arson attacks on more than 20 schools, a robbery of military weapon from the $4^{\text {th }}$ Military Development Unit, the killing of monks, police officers, teachers, students and villagers, and an arson attack on the Islamic Council office in Yala, a province locating in the southern part of Thailand. The violent acts posed by those militants were considered terrorism, which were seen by the outsiders as a new round of terrorism. In 2002, the Thai Intelligence Agency declared that terrorism in the south of Thailand had come to an end because it was not supported by the majority of Muslim countries. This was consistent with the CIA's report (Manager Daily News, 2005). Therefore, the unrest in 2004 suggested that the problems might have arisen internally from a loss of influence or for benefit gaining of staff or local agencies (Manager Daily News, 2005) while the former Prime Minister, Thaksin Shinawatra, also confirmed that the incident was not related to transnational terrorism of any kind but it was a disruptive action of a few people using the methods employed by ordinary criminals.

Concerning the scale of problem, there are several viewpoints and opinions to the root of the problem especially the views of high-level civil servants and politicians of the country. For example, General Thammarak Isarangkun Na Ayudhaya, the former Minister of Defense believed that, according to the testimony and evidence, this was an attempt to groom young people to have a new political belief dictated by a religious school. It was believed that the action was a consequence of the need to achieve a political change (Daily News, 2012). Wan Muhammad Noor Matha, the former Minister of the Interior, believed that such situation was created from the actions of some thieves who were addicted to drugs and unemployed. It was unrelated to local politicians or community leaders. General Han Lenanon, a former Commander of the $4^{\text {th }}$ Regional Army, also confirmed that the terrorist group in the three southern border provinces was the militants who tried to create a feud between the Buddhists and Muslims. This was not an act of Islam, but was actually opposed to Islam with an intention to create a religious war (Manager Daily News, 2005).

The problem was linked to issues of political controversy. The local MPs, which belonged to the Wada group, and local religious leaders who campaigned for local politicians harshly criticized the operation of the $4^{\text {th }}$ Regional Army and especially at General Thammarak Isarangkun Na Ayudhaya, for his excessive response to the situation. The local MPs and religious leaders believed that the problem was related to the fact that people in the local community did not provide information and did not cooperate with the government because they did not 
have faith or trust in the government or, in some cases, felt suspicious of the government's intention. This is a crucial factor that can allow terrorism to grow and expand. The problem needs the government's attention and investment in social costs. Thus, the problem cannot only be resolved by force and the state power to suppress the conflicts. Such action can provoke a backlash. The government has to understand that Muslim communities are part of the local communities in the southern border provinces. They have ownership of the communities, their unique culture, and religious belief. The government needs to change the attitude towards the Muslim communities. To be able to develop and maintain the state, the government must allow equal rights and freedom to the Muslims to realistically and appropriately manage and govern their own communities (Techapeera, 2004).

\section{The Conflict between the State, Terrorists, and Game Theory}

In the past 10 years, terrorism in the south of Thailand has drawn an attention from around the world, especially in the humanity and social sciences studies. Before the unrest in 2004, the southern communities lived their lives peacefully. Because of the geographical features of the south of Thailand, the majority of population in the south worked in rubber plantations. Their routine involved rubber tapping and collection in the plantations from dawn until midday. After that, they spent the rest of the day socializing with others in the community. In the southern area, not including Songkhla and Satun, 85 percent of the population was Muslim. Most population practiced agriculture while a few people were civil servants. The Buddhists and Muslims in the community lived alongside one another and supported each other through social economic activities such as selling and buying agricultural products in the community.

After the unrest occurred, several questions were raised to find the cause and motive of such act including why it happened in the southern border region. Many theories have been employed to explain the phenomenon of the situation and have not yet answered all the questions. It seems that the insurgents did not aim only for an impact on the government, but also an impact other governing bodies such as politicians, social institutes, economic system, which the insurgents considered as their enemies (Friedland, 1985). The operation might also aim at the ratification of the group whereby an impact of the operation caused a direct and indirect damage to the economy of the state and the local communities. This type of damage was considered worse than natural disasters because it decreased a sense of security in the communities with high risk from terrorism and the surrounding communities, which indirectly had an impact on a decrease in tourists, commercial activities, and business activities. This also affected the government budget allocation, which means most of the budget was wasted on national security instead of in stimulating the economy of the country.

However, the acts of terrorism would not meet their goals if it was not through the media. In other words, the target of terrorism was not directly to destroy, but to create terror as a means to an end to create a sense of insecurity and lack of safety in the community. This would make it easier for the terrorist to manipulate the state or the target community for their own purposes. These tactics of terrorism were not at all new measures. They have been intentionally employed for a long time (Schmid \& Jongman, 1988).

When considering the tactics of terrorism and the situation in the southern border provinces, it can be said that the issues concerning the current terrorism are as follows (interviews with government agencies, 2012).

Firstly, the conflict over a political ideology is long-standing and has been used by the terrorist group to create a violent act to claim the separation of the region. The separatist ideology started nearly 100 years ago when Haji Sulong, the founder of the Pattani People's Movement, launched a petition campaign to the government. The campaign disappeared many years later.

Secondly, the conflict over drug dealing is an act with financial motivation. It is a crime between the drug dealers and drug users while political issues have often been raised among the campaigners.

The third conflict involves religious motivation. A campaign concerning inequality between the Buddhist Thais and the Muslim Thais, especially those who did not work for the government, was raised. For example, it was questioned why female Muslim students who studied in the public school did not wear hijab (Note 1). The question of inequality started a new feud in the area.

Therefore, the unrest in the south of Thailand rooted from several issues and resulted in different tactics and operations (Enders \& Sandler, 1993). The separation of the borderland was not the only motivation of terrorism. Other motivations also involved political conflicts, especially the election campaigns and border trading problems. Separatism was argued to have very little influence in the new form of terrorism in the south. It was an old ideology which was said to be long gone. It was concluded that the main reasons of the conflicts were personal issues and drug dealing problems. The new insurgents tended to primarily target the government officials as the more lives of the government officials were lost, the more fear was created among the public. As 
a result, a sense of security in the community was lessened. The second target was the people in the community. Targeting the people in the community was to impose direct fear to the community. If there were 20 families in the village and one family was killed and burned, the other 19 families would live in fear and were very likely to leave the village (interviews with government agencies, 2012). This tactic of terrorism aimed for a direct impact to the target audience.

These inhumane actions in attacking innocent people could be seen as outrageous and irrational for most people. However, such actions could create a politically motivated impact more easily than other tactics. These inhumane actions are actually considered justifiable according to the game theory. In other words, although the actions, in this case the illegal actions, were conducted with limited resources, the value of the actions was determined by the profit gained from the actions. Therefore, it could be said that killing the innocents, although it was despicable, could create a huge political impact on the country with the minimal investment or "the effectiveness of the acts of terrorism". The behaviors of the terrorists in the southern border provinces in making rational decision within a limited cost consist of seven steps of actions as follows; Step 1: creating fear and anxiety to the public, Step 2: attacking government officials, Step 3: creating distrust between the Buddhist Thais and the Muslim Thais, Step 4 to 7: employing the falling leaves tactics, for example bombing including car bombs, killing teachers and monks. These actions were intended to create shock and terror to the local communities and made them leave the region without using any other forces. When the seven steps had completed, the cycle could be repeated. When a new factor emerged, actions could be adjusted to achieve the goal.

From the above hypothesis, it can be said that the behaviors of the terrorists depended on a rational decision in an attempt to integrate the resources available as a step to achieve the goal. When analyzing the conflict between the state and the terrorists in the southern border provinces and applying the game theory to the current problems in the region, it shows that those acts of terrorism which seemed to be outrageous and irrational were actually rational and justifiable under the conditions of the terrorists themselves. From the view of the game theory, the benefit of their actions could compensate the costs they invested. This game consisted of a few players, namely, 1. the terrorists, 2. the members of the public who supported the terrorist group, 3. the state, 4. the members of the public who had been affected by the acts. Each player was assumed to have an incomplete different set of information. This seemed to be a common practice in the society. In public policy-making, the state tended to make decisions according to the information they acquired and might have disregarded useful information from different sources. As a result, the state could make a mistake in conflict management policy-making. (Anusorn Thamjai, 2004).

The game theory, therefore, can be used to make sense of the unrest in the south of Thailand and the participation between the state and other players. The members of the public made a decision based on the information they had which was different from the information the state withheld. As a result, the interaction between the state and other players was a "not knowing the enemy and not knowing themselves" interaction. This created a new strategic relationship in the economic interaction or a game (Anusorn Thamjai, 2004).

\section{Studies on Game Theory}

What is game theory? Game theory is a study of strategic decision-making which uses mathematical models of conflicts and cooperation between intelligent rational decision-makers. Game theory has been used in economics, social sciences, political science, and psychology. It is also used in the study of behavioral relations (Myerson, 1991). Game theory was derived from James Waldegrave's idea in 1713 regarding a belief that one person's behavior results from others' behaviors. Game theory was first used in zero sum (Note 2) games. It was then developed into other games, for example Battle of the sexes, Blotto games, cake cutting, chicken. Game theory is also used to describe social behavior and political interest groups.

Nowadays, game theory has extensively been used by many scholars. More than eight scientists who employed game theory in their works received Nobel Memorial Prize in Economic Sciences. The key concept of game theory is equilibrium concepts. In social sciences, it is believed that if equilibrium occurs, it will reflect human behaviors and reactions to the event which is a crucial factor of game theory. However, game theory has been widely criticised as the theory was created based on a radical rational decision and may be opposed to the morality of the society. For example, the assumption that the game players will do everything to win the game or gain the most profits or Homo economicus model seems to be an extreme capitalist idea and it may not be rational from a psychological point of view. Nonetheless, game theory may be used to examine human nature. Human beings are selfish and will make a decision primarily based on their own benefits. Therefore, it can be said that game theory is actually based on a practical assumption of human behaviors. 


\section{Confrontation Game between the State, Its People, and the Terrorists}

The game between the state and the terrorists is based on the interests of different groups of people under the structure of blinding agreement. The interaction of the terrorist acts does not show an explicit demand or have a specific pattern. The state, therefore, needs to be prepared at all time and come up with different strategies to tackle the problem. The state's confrontation strategies can be seen in forms of 1 . The state increases the costs in dealing with terrorism. 2. The state reduces the incentives of the acts of terrorism. 3 . The state increases the incentives in not committing a terrorist act. These confrontation strategies are conducted with the innocent people standing in the middle and being affected by the confrontation from both parties. To choose the right strategy is, therefore, very subtle, complicated, and difficult (Frey, 2003).

In Thailand, the government has been employing different confrontation strategies in dealing with terrorism in the southern border provinces, for example, increasing the government budget in dealing with terrorism and engaging the government officials from different agencies, soldiers, and police officers in the operations in the southern border provinces by setting up a new agency working directly to the central command center. Regarding to an increase in the incentives in not committing terrorist acts, SBPAC (Note 3) was set up to monitor the work of government agencies in the five southern border provinces and to coordinate with security forces. The center reports to the Prime Minister Office directly. One of the center's missions is for improvements in the education of young people in the southern border provinces.

However, the confrontation strategies in the southern border provinces did not manage to eradicate terrorism in the area. It could only alleviate the suffering of the people to some extent. This is because the unrest in the south of Thailand is a very sensitive and fragile issue. It stemmed from an ethnic and religious separatist insurgency in the past. The ideology has passed on from generation to generation by a group of people who are skilled public speakers with psychological tactics. Therefore, the government had to employ a very subtle measure in dealing with those accused of committing a terrorist act. For example, when an individual was arrested and charged with terrorism-related offenses. The government preferred using an ideology adjustment measure to an aggressive punishment. An eradication strategy to get rid of the terrorist group might have a ripple effect on the whole community and create distrust in the government. Therefore, it was difficult for the government to keep the balance of giving sentences to the crimes they committed and to readjust their ideology, retrain, and resocialize them to get back into the community.

\section{The Government's Solutions Measures}

An alternative solution for the government is providing a different set of information to the public. This set of information may not be the same as the official information being used by the government agencies. For example, when a violent incident occurs, an attention should be diverted from a terrorist act and the incident should be treated as a crime so that the general public is not seen as a target of the incident and creates a panic. By employing the game theory to explain the situation, it can be explained that this is a game which is played by the state, the terrorists, and the public. Another player who should be added into this game is the media. The media plays a very important role in this game because the information they give can worsen the situation. Although the media has low cost utility in the game, its impact to the sense of security of the public is immense. It could be used as an effective tool by the insurgency.

Although the supporters of terrorism and the terrorists may not have the same goal, they can benefit from using the same method in committing the violent acts. This is seen as an external cost of terrorism. The result of such acts costs the government greatly. For example, when the terrorist acts were committed, the people in the community lost a sense of security and fled from the area. This allowed drug dealers to have an opportunity as a free rider to trade in the area freely as the community was too scared to report for fear of their own safety while the authority's priority was to deal with terrorism and other crimes committed in the area were put on hold. In the meantime, it allowed the terrorist group to seize control of the community and use it as their base or a training camp of the separatist insurgency. Therefore, without having enough information and understanding the motives of such acts, the public can be manipulated by the terrorists to achieve their goals. As a result, if the government is keen on seeking for an appropriate solution to this matter, the government must find a measure to prevent the supporters of terrorism from receiving external benefits from the terrorist acts. The incentive the supporters receive from the situation encourages further undesirable acts (Brook, 2002). The government must tighten the measures in dealing with those free riders.

Sandler and Arce proposed two types of counterterrorism measures; pro-active measures and defensive measures. Pro-active measures include destroying terrorists' resources (e.g. training camps), capturing their members and supporters, and curbing their finances. Defensive measures aim to make their attacks more costly or to reduce the 
jod of their success, such as, the installation of metal detectors or issuing a regulation against arms trade. Some defensive measures may affect the public's security. For example, the right to bear arms allows people to defend themselves in an emergency situation. Therefore, to tighten the arms trade regulation may result in the people having a problem accessing firearms if needed. In Thailand, several defensive measures have been used to tackle terrorism. In using defensive measures, the state must provide enough information to the public and the same enforcement of the measures is required in all areas. Double standards of enforcement can increase tension and conflicts in the community. The members of the public must be informed to have an understanding that the limited rights they have is compensated by the safety and security they will receive. This can also decrease distrust between the public and the government agencies. In other words, it is a free rider for the government.

The final measure which has been used by the Thai government is to increase incentives in not committing a terrorist act. The measure encourages those who committed a terrorist offense or were involved in the terrorist group to work with the government agencies. In return, they are offered with better incentives or opportunities in life and finally give up in taking part in the group. The government is aware of the close connection of the terrorists and the community and by working with former members of the terrorist group the government can also benefit from the information about the group from their cooperation as well as using them to distribute the state measurement in suppressing undesirable acts to the terrorist group (Bueno de Mesquita, 2005).

\section{Game Theory, Situations, and Community Adaptation}

According to the game theory, the interaction between the players of the unrest in the southern border provinces can be seen as follows. Firstly, the government tended to use defensive measures in dealing with terrorism. Secondly, defensive measures could cause anxiety in the local community and distrust in the government if the community did not receive appropriate information or the information was distorted by the media. Thirdly, the pro-active measures would be effective only when the terrorists had a political motivation. This measure could be complicated and sensitive if the government did not receive enough information or received wrong information which led to an inappropriate operation such as arresting a scapegoat. This could create more conflicts between the government and the public.

The government, therefore, can achieve better results by using defensive measures which, according to the game theory, will be able to predict the behaviors of the players provided that all the players are rational. Although the game theory may be able to explain the strategies of the players, it is not able to explain the motives of the players in taking part in the game. Concerning the unrest in the south of Thailand, the game theory provides an explanation of the players' behaviors and that the confrontation strategy was done with rational decisions. The external factors including the information provided to the public also affected the community behaviors. The community compared the cost of continuing living in the area to the benefits they received and the benefits they expected to receive by using the information provided by other players in the game such as the media, the government, and the terrorists. It is obvious that the media was one of the primary players in the incident in 2004 The intensity and the violence of the incident portrayed in the media and the distortion of the information from the media had created a tremendous fear among the local community. People in the local area had considered the payoff would be worth more than continuing living in the area. As a result, they decided to sell their land and properties and move out of the area which was considered as having high risk of terrorist attacks. At the same time, people from other communities and tourists were too afraid to come to the area.

The rest of the people in the area whose cost in relocating was too high to move continued to live in the area with fear and anxiety creating a separation between the Buddhist Thais and the Muslim Thais. The media who projected themselves as a perfect information source played a role in guiding the community actions and creating motivations of other players in the game. At the same time, the players formed a subgroup of other players who were from the same social status, political ideology, and religious background. This created a more complex game with different groups of players having different interactions between each other with different motives and goals.

After the incident occurred, the initial response to the situation of the people in the area was to move out. This was an expected reaction anticipated by the terrorist group according to their seven steps strategy. The terrorist group also used a strategy to create distrust among the people in the community. They accused the Buddhists in attacking the Muslims and vice versa in an attempt to create a division between the two ethnic groups. However, after people reconsidered the gains and losses of relocation as well as an opportunity to receive more information from other sources, the needs to earn a living outweighed the costs of moving out. The people then decided to move back and adapted to the changes in the community. To compensate the costs of living in an area with high 
risk of terrorist attacks, the local people learnt to negotiate from the government for more benefits. They also started to protect their own community by setting up the village security unit and neighborhood watch volunteers. They also applied for the government funding for career development, improving education for young people, and scholarships for medical students as they realized that more doctors were needed in the local community. The support from the government was seen as a double-edged sword. While the budget was needed in community development and allowed positive activities to meet the community's needs, the lack of supervision and efficient tracking and evaluation system from the government agencies that were responsible for those projects resulted in ineffective outcomes. The projects were not sustainable. There was no plan for the future of the projects. The community only relied on the funding from the government and without further funding the community was not able to be self-sustained. The support from the government made the community feel accustomed to being spoon-fed. When the funding stopped, the community felt they were abandoned by the government. It could provoke outrage and conflicts between the community and the government.

\section{Future of the Southern Border Provinces}

The southern border provinces have been restored and the suffering of the community from the terrorist attacks has been alleviated. The communities have adapted to the changes while the terrorist group do not have long-termed financial support and a lot of the members are tired of a life of a fugitive and decided to quit being the members of the group. Less and less incidents have occurred in the past few years. Moreover, as the ASEAN Economic Community aims to establish a common market by the end of 2015, the government planned to use the three border provinces as a free trade zone. It is expected to boost the economy of the region, especially the trade between Thailand and Malaysia. People living in the southern border provinces have an advantage of using Thai and Malay language in their everyday conversation and in business transactions. At the same time, the government has encouraged young people to learn English and Chinese to cope with visitors from further fields.

In terms of an education strategy, Islamic University was founded in Yala and Pattani to encourage more young people to attend further education. International students from China, Japan, Brunei, and Qatar also attended the university. The Islamic University is attractive to international students because of the demographic diversity of the region and several languages have been used for communication. There has been a discussion whether Pattani province could be allowed to have a status of an independent state of Patani Darussalam. The consultation with the public will need to be done before any policy can be made about the issue. Although becoming an independent state may contribute to the local economy, plans and preventive measures must be sought in case the state cannot sustain its autonomy.

Most people in the southern border provinces said they wanted to see an increase in local economic growth and free trade in the community. It is hoped that a lucrative market will reduce the incentives of the terrorist group. The vibrancy of the local community will increase the security measures from the government and from the outside world. Moreover, the southern border provinces are rich with natural resources which are suitable for both agricultural trading and tourism industry. Nonetheless, religious issues are still the key factor to the community.

Any future government policies will need to consider religious backgrounds of the community. The consultation with the community is crucial in policy planning. The government needs to make the community understand the objectives of the policies and to gain trust from the locals. Although the economy growth strategy may help reduce the incentives of terrorism, the current transnational terrorism may encourage the terrorist group to evolve and come up with different strategies. The government needs to be prepared and be ahead of the game.

\section{References}

AFP. (2008, March 19). Bloodshed part of daily life in Thailand's Muslim south.

Brook, R. A. (2002). International Security: Civil Military Relations; Terrorist \& Militant Organization. Department of Political Science, Marguette University.

Bueno de Mesquita, E. (2005). Conciliation, Counterterrorism, and Patterns of Terrorist Violence. International Organization, 59(1), 145-176.

Daily News. (2012, August 1). Yala investigation during the unrest in the southern of Thailand.

Enders, W., \& Sandler, T. (1993). The Effectiveness of Anti-Terrorism Policies: Vector-Autoregression-Intervention Analysis. American Political Science Review, 87(4), 829-844.

Frey, S. B., \& Luechinger, S. (2003). Three Strategies to Deal with Terrorism. Economic Papers, 27(2), 107-114.

Friedland, N., \& Merari, A. (1985). The psychologicali mpacto f terrorism A: double-edgeds word. Political 
Psychology, 6, 591-604.

International Herald Tribune. (2007, June 14). Police say bomb at soccer match in southern Thailand wounds 14 officers.

Interviews with government agencies, the unrest situation of the southern border. (2012, August 1).

Manager Daily News. (2005, September 21). Nineteen hours unrest in Tunyonglimo.

Roger, M. B. (1991). Game Theory: Analysis of Conflict (p. 568). Cambridge, MA: Harvard Univ. Press.

Schmid \& Jongman. (1988) Political Terrorism: A New Guide to Actors, Authors, Concepts, Data Bases, Theories and Literature. Harvard University. Program on Nonviolent Sanctions in Conflict and Defense.

Techapeera, K. (1996). New Cycle of Property War: Using Terrorist to Destroy Community Development. Matichonraiwan (Papers Vol. 28).

Thamjai, A. (2004). Business Cycle: Krungtepturakit (Papers Vol. 36).

Waldegrave, J. (1713). Dictionary of National Biography. London: Smith, Elder \& Co. 1885-1900.

\section{Notes}

Note 1. The head covering that Muslim women wear.

Note 2. Zero-sum game is a situation in which one participant's gains or losses of utility is balanced by the losses or gains of the utility of the other participant or, in other words, a participant will win over the losses of others. Zero-sum game focuses on winning and losing only no matter how many players are involved. The winner gains the all profits from the game and the losers do not gain any profits.

Note 3. Southern Border Provinces Administrative Centre.

\section{Copyrights}

Copyright for this article is retained by the author (s), with first publication rights granted to the journal.

This is an open-access article distributed under the terms and conditions of the Creative Commons Attribution license (http://creativecommons.org/licenses/by/3.0/). 